\title{
INFLATION AS AN INSTRUMENT OF MONETARY REGULATION
}

\author{
Hasan ALPAGO*
}

\begin{abstract}
Inflation is one of the fundamental parameters that provide information about the progress and general outlook of an economy. The main aim of this study is therefore to evaluate economic competence in the fight against inflation using a scientific system. The more information that is disseminated about a problem and its solution, the greater the chances of success. Because the fight against inflation is not just a fight that the central bank will wage alone. If inflation is a problem especially for the lower- and middle-income brackets, information dissemination is particularly important here. With the invention of money, the economic power that manages money struggled with inflation, which reduced the value of money. From this perspective, inflation from the past to the present has been the focus of a constant debate. On the other hand, everyone knows more or less the concept of inflation. However, there are very different opinions about its causes and consequences. So that, due to the importance of the topic, inflation, along with its causes and consequences, was viewed pluralistically in this study. Here the causes and consequences of inflation are examined, particularly within the framework of mainstream theories. This is the inflation perspective of economists like Smith, Ricardo, Marks, Fisher, Keynes, and Krugman. The problem scrutinized as part of a comparative analysis.
\end{abstract}

Keywords: Inflation, Deflation, Value, Crisis, Devaluation, Devaluation.

\section{PARASAL DÜZENLEME ARACI OLARAK ENFLASYON}

ÖZ

Enflasyon bir ekonominin performansı ve genel görünümü hakkında bilgi veren temel parametrelerin başında gelmektedir. İşte bundan dolayı bu çalışmanın temel amacı enflasyon ile mücadelede ekonomik okuryazarlığı bilimsel bir sistematikle değerlendirmektir. Gerçekten de bir sorunun kayağı ve çözümü hakkında bilgi taba yayıldıkça başarı şansı daha da artar. Çünkü enflasyonla mücadele sadece merkez bankasının tek başına yürüteceği bir mücadeleden ibaret değildir. Enflasyon özellikle düşük ve orta gelirli sınıf için bir sorun olduğunda bilginin tabana yayılması burada ayrı bir önem arz etmektedir. Paranın icadıyla birlikte parayı yöneten ekonomi erki paranın değerini azaltan enflasyonla mücadele etmek zorunda kalmıştır. Bu açıdan bakıldığından geçmişten günümüze enflasyon sürekli bir tartışma konusunun merkezinde olmuştur. Öte yandan enflasyon kavramını herkes az çok bilir. Ancak buna rağmen sebep ve sonuçları hakkında oldukça farklı görüşler söz konusudur. Konunun bu önemine binaen bu çalışmada enflasyonu sebep ve sonuçlarıyla plüralisttik bir bakış açısıyla mercek altına alınmıştır. Burada özellikle ana akım teorileri çerçevesinde enflasyonun neden ve sonuçlarını irdelenmiştir. Smith, Ricardo, Marks, Fisher, Keynes ve Krugman gibi ekonomistlerin enflasyon bakış açıları bu. Çerçevede karşılaştırmalı bir analizle mercek altına alınmıştır.

Anahtar Kelimeler: Enflasyon, Deflasyon, Değer, Kriz, Devalüasyon, Devalüasyon.

Atıf: ALPAGO, H. (2021). “Parasal Düzenleme Aracı Olarak Enflasyon”, İMGELEM, 5 (9): 281-291.

Citation: ALPAGO, H. (2021). “Inflation As An Instrument of Monetary Regulation”, İMGELEM, 5 (9): 281 291.

Başvuru / Received: 12 Eylül / September 2021.

Kabul / Accepted: 18 Kasim / November 2021.

Derleme Makale / Review Article.

\section{INTRODUCTION}

Most people without a general economic education perceive inflation as just a negative progress. However, inflation is a mechanism that regulates the concept of value. This situation continues to act as a stabilizing element in the barter-like exchange system and in the paper

\footnotetext{
* Dr. Faculty Member, Nisantasi University, IISBF, E-mail: hasan.alpago@nisantasi.edu.tr, ORCID Number: 0000-0001-7695-2794
} 
money system as well. Below zero, i.e., negative inflation, is an undesirable situation in this respect, or an inflation rate of over two percent is undesirable. In other words, a very low inflation rate leads to deflation, i.e., an overvaluation of a country's currency, while high inflation makes the currency extremely worthless.

From the invention of money to the present day, a money-related topic has not been discussed as much as inflation. Indeed, inflation is a fact that has been constantly debated by economists, managers, and citizens from yesterday until today. More importantly, economists have tried to explain inflation by developing theories and models on the subject and strategizing to find a solution to it, and research in this direction is ongoing.

On the other hand, inflation is always present at different rates in each country. In this respect, inflation is one of the central banks' main tasks. Because inflation is a parameter that threatens price stability. Therefore, economic administrations generally set an inflation target according to the conditions in which they find themselves and the economic indicators available to them. They pursue a monetary and fiscal policy in this direction. As a rule, the uncertainty band is set at 2 points above and below the inflation target and tightened if there is a deviation from it. Today, a higher inflation rate is sought for underdeveloped and developing countries than for industrialized countries. The reasons for this approach lie in the difficult economic framework conditions. The main reasons are chronic economic problems, structural problems, non-transparent management style and, above all, insecurity in all areas.

Within the framework of these general perspectives, in this study, we tried to bring a more universal approach to the subject by focusing on the causes, consequences and solution proposals of inflation within the framework of different theoretical approaches. In the study, in particular, the approaches of Keynes, Hayek, Marx and Krugman were evaluated with a comparative analysis. As a result, an attempt was made to make the subject more understandable through a pluralistic method.

\section{Theoretical and Conceptional Framework}

The term inflation is of Latin origin and corresponds to the common medical term inflammatory reaction, which means high fever or extreme reaction. In medicine, inflammation is the body's normal response to any harm. Inflammation means that our white blood cells protect us from an external factor such as bacteria or viruses, and inflammation occurs with any disability. For example, when one has difficulty exercising, the injured area usually becomes 
painful, swollen, and inflamed. Similarly, inflation is the situation faced by excessive monetary devaluation in the economic literature.

Deflation can be defined as the opposite of inflation. However, it can have just as negative an impact on an economy as inflation. Deflation leads to a sustained decline in the price level. It can decrease because the circulation of money is declining or because the overall economic supply exceeds the overall economic demand. As a result, continuous price reductions can lower wages and increase unemployment in the medium and long term. In this way, the country's overall economic performance is falling. For example, if we try to explain it medically, it means the contraction and narrowing of the vessels. Here, as with high blood pressure, as the fever rises, the body is slowed down so much by blood withdrawal and the slowing down of the blood vessels that it can no longer carry out its functions, i.e., its activities. Consequently, while inflation can be thought of as blood pressure above normal, deflation is the slowing down of blood pressure so that it cannot complete the cycle.

The research questions of this work are:

- Why and how does inflation arise?

- How do theories rate inflation?

\section{Inflation and Deflation and Economic Equivalent}

In order to cope with the economic difficulties caused by the corona pandemic, the governments adopted stimulus packages and borrowed billions of euros. However, deteriorated economic equilibria are not easy enough to be resolved with such palliative approaches. Inflation in particular is a reality that must be vigorously combated in this process (Risse 2021). When inflation is seen as a significant threat to economic stability and growth, USA as well as supranational unions such as the European Union, as in every country, make it their basic principle to keep inflation at a certain rate in order to realize their economic targets. In this respect, the monetary policy of the European Union is based on an inflation target of $2 \%$. There are two main reasons for this inflation policy of the EU (Benati 2009):

- To prevent inflation from falling below zero to avoid deflation

- To prevent inflation from rising above $2 \%$ to ensure price stability.

The EU follows a policy of balance in the economic field as well as in the political field. In this framework, monetary policy and fiscal policy are based on specific objectives. Here, the primary objective is to maintain a sufficient distance from the zero percent inflation rate in line 
with the monetary policy. In this way, it is desired to prevent inflation from falling below zero, that is, from turning into deflation. In other words, very low inflation is not desired due to the deflationary effect. In other words, deflation, like inflation, is seen as a threat to the economy. The second and most important target is low inflation for price stability. Thus, both very low inflation and very high inflation are combated. As a result, an equilibrium policy is followed in the economy.

\section{The Sources of Inflation}

There are two main types of inflation. These are classified as supply and demand inflation. On the other hand, there are several reasons for inflation. For example, supply inflation is characterized by rising raw material prices or production factors such as wage and non-wage costs. This makes the manufacturing process of many goods more expensive. Because of this, companies raise the prices of their products and pass additional costs on to consumers. As a result, purchasing power decreases over time. Because consumers need to get less value for their money than before. Furthermore, such deflation can force investors to postpone costly investments so that continuing existing resources without additional investment can raise the prices of goods and services. This cost inflation can be caused by an increase in the prices of imported goods. For example, when the price of crude oil quadrupled worldwide, as it did during the 1973 oil crisis, so did the cost of energy resources, which are the main driver of production. Thus, the production cost increased. Thus, the companies reflected these costs in their prices and the tendency to new investments decreased. As a result, unemployment and inflation began to rise at the same time (Bordo 2010).

In contrast, when there is inflation in demand, prices rise because consumers demand certain goods or services more frequently. However, if demand exceeds supply and there is speak to full employment at the same time, demand can inflate. In this case, companies may not be able to meet the increasing demand by increasing production. Thus, consumer prices are increasing. In fact, the investment is made because of a long-term process. However, short-term volatility causes monetary fluctuations such as inflation and interest rates. The other causes of inflation can be listed as follows (Bryan 1997):

- Imbalance in income distribution

- The long-term slow pace of cyclical economic activities

- Government policy to reduce household incomes in the form of taxes 


\section{Inflation Theories}

Inflation is generally defined as a process of continuous increase in the average price level. Inflation can be observed to a greater or lesser extent depending on the conditions of a country's economy. Various theoretical approaches in macroeconomics try to explain the phenomenon of inflation. These inflation theories can be classified mainly according to two main institutional frameworks, monetary and non-monetary (Birinci 2011).

Inflation, which is defined as the rapid and continuous increase in the general level of prices, does not mean that the price or the price of anything has increased only once in any given period. According to this definition, inflation is an imbalance situation that arises from a dynamic rather than a static process. From this point of view, inflation is an economic parameter that measures whether the goods and services circulating in the market are in equilibrium. Therefore, an equilibrium situation can be created by lowering or increasing the rate of inflation to maintain market equilibrium. To put it more clearly, it is an economic instrument that regulates and measures money-related imbalances in the market.

\section{Monetary Inflation Theories}

According to the classical theory, an increase in the money supply is the only cause of inflation. In fact, the classical school's conception of inflation is based on theories developed in the sixteenth century. According to this theory, the rise in the general price level develops in relation to the rise in the money supply. At a time when in the 16th the general price level. Ricardo later embodied this view further and gave the shape of quantity theory to the classical school of quantity. Ricardo defended the view that the money market is a dynamic mechanism and will balance itself without interference. Ricardo inspired this thesis by Bodin and Hume. Fisher, who is considered to be one of the most important representatives of the classical school, later expressed this approach empirically with the formula (Erdoğan 2005).

M. V = P.T.

The free monetary policy of traditional institutions has two main pillars. The first of these is that money is only kept as a tool for shopping. According to this, rational people will not prefer to hold money for long because they only hold money for shopping and thus there will be no unused money in the market. Second, according to the classic school view, every supply creates its own demand. Thus, money supply and demand as well as goods and services are automatically balanced (Tobin 1972). 
Monetary inflation theories can be evaluated in two sub-headings, mainly the quantity theory and the monetary explanatory approach of Keynesian theory. According to the quantity theory, the purchasing power of money, expressed as units of goods, is largely determined by the quantity of money. The degree of this determines the value of money.

The quantity theory is expressed as MV $=\mathrm{PT}$. The left side of this equation reflects the product of the amount of money in circulation in the economy during a given period and the rate of exchange of hands (MV). The right-hand side represents the product of the amount of goods and services that change hands in a certain period (one year) and the average price of these transactions (PT). Accordingly, the monetary value (MV) of the volume of transactions in the economy is equal to the sum of the payments during these transactions.

The value of money is inversely proportional to the prices of goods and services. In economics, when the general price level rises, when the general price level rises, the monetary value rises. The value of money is expressed by the formula as follows (Illing 2009):

$$
\begin{aligned}
& \mu=1 / \mathrm{P} \\
& \mu=\text { monetary value } \\
& \text { P: General price level }
\end{aligned}
$$

The decline in the purchasing power of money in relation to other goods and services means that it can buy less of them than before.

$$
\begin{aligned}
& \mathrm{M}=\mathrm{kPT} \\
& \mathrm{P}=\mathrm{M} / \mathrm{Kpt} \\
& \mathrm{k}=1 / \mathrm{v} \\
& \mathrm{k}=40 / 200=1 / 5
\end{aligned}
$$

Accordingly, the fact that $\mathrm{k}=1 / 5$ in an economy shows that people want to keep $1 / 5$ of their income as money in their wallets or demand bank accounts.

The expected inflation is stated as the expected increase in the general price level. It is determined by multiplying the ratio between the expected increase in the price level in the current period and the price level in the previous period by 100 .

$$
\pi^{e}=\frac{\left(P_{t}^{e}-P_{t-1}\right)}{P_{t}{ }_{-1}} \times 100=\frac{\Delta P_{t}^{e}}{\Delta P_{t}{ }_{-1}} \times 100
$$


For example, let's say a service cost \$1,000 last year. However, this year it is expected to pay $\$ 1,008$ for the same service. In this case, considering the increase in the price of the product as inflation, the rate of inflation can be calculated as follows (Steele 1989): Inflation = $(1008-1000) / 1000=0.8$ results. In this case, the inflation rate for this service is accepted as $0.8 \%$.

Monetary inflation theories consider excessive expansion of money supply relative to real production of goods and services as the most important cause of inflation. In other words, these theories mainly focus on the money supply as an explanatory factor for inflation. The price level is then ultimately determined by the quantity of money in circulation and the velocity of circulation. Increasing amounts of money inevitably lead to inflation. Monetarism, which is a school of thought in the field of monetary inflation theories, therefore considers a restrictive monetary policy as a basic approach in the fight against inflation. Basically, monetarists think that money supply control has only a real short-term economic effect. In addition, monetarists are skeptical of the fundamentally real economic effects of neoclassical theorists' monetary policy. Consequently, there is a direct link between monetary policy and inflation (Görgün 2012).

According to Friedman, it is the Keynesian approach that reduces the role of money in economic analysis. However, according to Friedman, inflation is a monetary phenomenon, and the main cause of inflation is an increase in the money supply. In addition, the inflationary effect of public expenditure $(\mathrm{G})$ depends on how public expenditure is financed. On the other hand, approaches like the structuralist school, in contrast to the classics, argue that economic structure and its changes are the main cause of inflation (Friedman 1995).

\section{Non-Monetary Theories of Inflation}

These theories try to explain inflation in terms of structural changes on the supply or demand side of goods. Accordingly, we talk about demand pull inflation or supply pressure inflation (cost pull inflation). Demand inflation results from rapidly increasing demand for goods for which supply cannot be adjusted fast enough. Price increases are the result. In the case of supply pressure inflation, rapidly rising production costs, such as labor costs or raw material prices, cause prices to rise (O’Neill 2017):

- Demand Pull Inflation: In this case, inflation exceeds the total economic supply of general economic demand that can be created with current production capacities. In this way, the supply does not meet the demand and the producers prefer to increase their 
profits by raising their prices and selling the same goods at a higher price in response to the increasing demand. Thus, an increase in the general level of prices occurs.

- Cost Push Inflation: Here, if costs such as wages, taxes, loan costs, intermediate imports increase faster than productivity increases, inflation increases.

- Profit Push Inflation: Generally, market dominating forces such as monopoly and oligopoly firms cause inflation by emphasizing that profit is the determinant of prices.

- Imported inflation: It is the transfer of external inflation to the domestic market.

- Politically Caused Inflation: In the view of political inflation theories, inflation is a problem of power and political opportunity or a result of the central bank's anti-inflation policy.

\section{From Adam Smith to Keynes Inflation}

Adam Smith brought the power of the free market to inflation and value to the fore in his magnum opus, "The Wealth of Nations". Smith tried in his masterpiece to explain this with the theories of "homoeconomicus" and the "invisible hand". Smith's arguments, however, are not strong enough to guide policy in the case of an economic crisis. In fact, these questions were later analyzed more vividly by economists such as Keynes, Hayek, Ricardo, and Fisher.

The expansion of the money supply may initially result in a lower interest rate. This stance stimulates investment activity and consequently leads to an increase in aggregate demand through the income multiplier effect. Thus, inflation occurs when there is full employment in the first case. In this direction, Keynes establishes a connection between the level of employment and inflation. In a Keynes economy, falling unemployment tends to be associated with rising inflation.

Keynes argues that the economy defended by classical theories is not full employment, rising unemployment and imbalances cannot be automatically eliminated by the market mechanism, and the view that the downward flexibility of wages and prices is viewed as full employment is not confirmed. Keynes also notes that the view that the interest rate equates investment and growth in order to realize the full use of resources is wrong. The technical conditions of Keynes, the wage level, the size of the unused capacity of the factory and its workforce as well as the market and competitive situation determine the delivery conditions for individual products (Akalın 2016).

Monetary policy in the US is not very effective, according to Krugman. In this respect, the Fed should raise its inflation target. Like the ECB, the Fed's main goal is to keep interest 
rates under control within the $2 \%$ target. However, neither the ECB nor the Fed manage to achieve this goal, so they must revise their inflation expectations from time to time. From this point of view, one can say that today's economists like Krugman have more realistic approaches (Sever and Demir 2015).

Krugman suggests inflation as a tool to mitigate the effects of the crisis. Krugman argues that insufficient domestic demand and a slowdown in investment in a country cause the economy to enter a deflationary process, and high inflation can be a solution to get out of this situation. According to Krugman, there is an advantage in holding money as money in a deflationary environment where prices are falling as opposed to an inflationary environment. However, it has other costs to the economy. As a remedy, Krugman suggests that the central bank make more money available to the market, which sets off an inflation boom. According to Krugman's thesis, when inflation develops in the economy, when people realize that the real value of their savings has declined, people will inevitably tend to spend and, as a result, domestic demand will revive. Meanwhile, nominal interest rates, kept below inflation, will encourage companies to invest and the country will break the vicious circle that led to the crisis. Krugman added that the possibility of a country's currency depreciating further as the money supply increases could increase the risk of depreciation. However, this is less damaging than the deflationary effect (Krugman 2021).

Figure I. The Relationship between Inflation and Unemployment

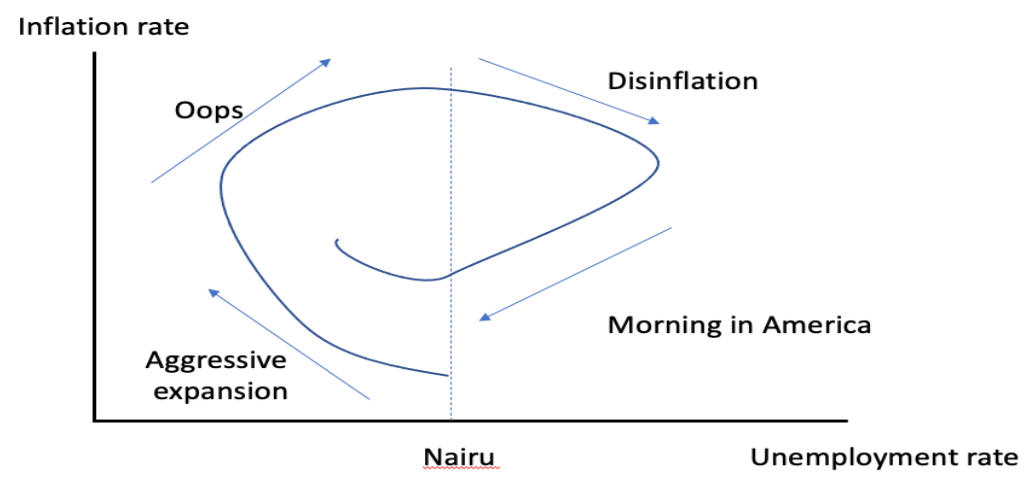

Source: Krugman, P. (2021).

As seen in Figure I, unless there are structural solutions in an economy, there is a vicious circle process between inflation and unemployment rate. In this case, when the economy management follows a policy to reduce unemployment, this time inflation starts to rise. However, when inflation-reducing policies are followed, this time, on the contrary, unemployment begins to increase. 


\section{Hayek and Keynesian Inflation Approaches}

The Austrian school economists like Hayek and von Mises propose neither inflationary nor deflationary policies to business leaders. Particularly, von Mises does not encourage governments to change the market's choice of medium of exchange.

After the global crisis period known in economic literature as the Great Recession of 1929, the depression-deflation crisis was replaced by another economic crisis dominated by the inflationunemployment spiral. Hayek argues that given this stagflations situation, Keynesian theories are insufficiently explanatory. Here Hayek has added another dimension to the crisis and inflation discussions by analyzing the phenomenon of stagflation in business cycle theory.

Keynes suggested that based on increasing public spending as a way out of the great depression of 1929, the state should take over the function of regulating the market without disrupting the functioning of the market economy. According to Keynes, increasing demand for consumer goods will, under certain conditions, increase investment. However, Hayek argues that this assumption is wrong. While Hayek defends the cyclical functioning of the liberal economy depending on the Austrian school, he sees the excessive expansion of the credit volume through state intervention in banks as the main reason for the crises (Atbaşı 2016).

As a result of the pressure from entrepreneurs on the state to provide low-interest money to increase investments, according to Hayek the market interest rate will be reduced, and the credit volume expanded. Thus, lowering the interest rate extends the production process and enables the capital goods industry to expand. In addition, the prices of consumer goods are rising because the consumer goods produced are not sufficient to be able to afford such a long production process. In this case, the price of capital goods goes down and investors lose. This disrupts the entire production structure and shifts the equilibrium. This disturbed equilibrium is restored by the rise in interest rates because of the rise in the price level of consumer goods compared to the price level of capital goods (Alpago 2018).

While the new loans created by the banks raise the price level, people who cannot increase their income at the same pace reduce consumption and thus the economy is forced to save. However, when credit inflation stops, the forced saving created by credit expansion is left to consumer spending, which allows the consumer goods industry to expand. The price increases caused by the expansion of the consumer goods industry reduce the profit rates in the capital goods industry and cause economic damage. 
These changes in the capital structure of the economy cause economic waves consisting of rises, crises and depressions. On the other hand, Hayek, who argued that the Keynesian Accelerator Effect, which claimed that increasing demand for consumer goods would increase demand for capital goods, was not always valid, instead advocated the concept of the Ricardo Effect. Ricardo and Hayek believe that an increase in real wages will lead to greater use of labor in the economy, which in turn means an increase in capital. While the real wage increase aims to increase the demand for consumer goods, one counteracts the fact that the production of capital-intensive goods is increasing (Steele 1989).

According to Hayek, the reason for the economic waves is the changes in the production structure that are caused by the monetary effects of the banking and credit structure of the capitalist system. Hayek sees the main reason for the crisis as the fact that Keynesian policies are causing credit inflation by lowering interest rates. According to Hayek, lowering investment costs through cheap credit opportunities without changing savings behavior and artificially increasing the return on investment by supporting effective demand are the causes of future inflation (Acar 2007).

Hayek also said that competitive practice can be a significant achievement in tackling money-related inflation. Allowing individuals to use a currency of their choice provides control against inflation and allows citizens to hold assets denominated in any currency. Governments will have more options to avoid inflation. Because a devaluation unit will direct people to other currencies.

\section{Hayek and Marxist Theory}

In contrast to Hayek's liberal approaches and resolutions, value in Marxist economics is based on the demand for that commodity by those who have money as opposed to the labor it takes to mine a particular commodity. Since it determines the true cost of a good or service, currency price fluctuations are negligible compared to the increase and decrease in the cost of labor of a good. Moreover, according to Marxist approaches, the proletariat, that is, the labor force, is the cornerstone of the functioning and balance of economic and social life. Accordingly, economic crises such as inflation, currency crises, current account deficits, with which the capitalist system is constantly confronted and also known as "market cleansing", will not repeat themselves once a labor-based system is established. Marx argues that the real nature of inflation lies in the cost of production as measured by labor. Due to the classical labor theory of value, it only depends on whether more or less work is required to produce a certain product at the required speed (Hiç Birol 2013). 


\section{CONCLUSION}

In the simplest sense, inflation can be defined as the increase in the amount of money in the market and the real depreciation of money due to this nominally increasing amount of money. In such a case, it is necessary to spend more than this currency to buy a product whose value remains constant. In other words, inflation describes the swelling of money and all kinds of money substitutes according to the volume of goods.

On the other hand, seeing inflation as the result of poor monetary and fiscal policy, rather than as the cause of economic crises, will be more effective in making more accurate decisions about how to fight inflation. Above all, inflation should be viewed as an indicator that measures the success or failure of an economic program pursued by a government. In this respect, the effectiveness and results of monetary and fiscal policy can be understood by evaluating the resulting inflation figures. Accordingly, measures can be taken, and program strategies changed. Against this background, the following conclusion can be drawn; inflation is a poor indicator of an economy, but it is also a warning sign of a recession, a crisis that ultimately warns of total economic collapse.

Despite different perspectives, inflation can be accepted as a monetary variable. Inflation rates are the most important parameter that indicates the purchasing power of money. In this respect, inflation rates, especially with globalization, are gaining particular importance for the domestic and foreign economic reputation and thus the credibility of the countries. From time to time, some countries seek to take advantage of not reflecting inflation numbers as they actually are in order to attract more FDI and provide economic stability. However, this approach not only undermines the international credibility of countries and institutions, but also complicates the ability to adequately deal with structural problems.

In this respect, the fight against inflation should be transparent and coordinated. As a result, there are different opinions about the causes and consequences of inflation, but inflation means a crisis for every economy in the medium and long term. To put it more clearly, inflation weakens this function of money, which is almost the only medium of exchange that enters our lives. Inflation will be a part of economies unless there are alternative means of exchange and valuation to money. It is important here how this relationship is regulated and how the balance is achieved. Although it seems that the rapid spread of cryptocurrencies will change the approach to inflation, a radical deviation and change in functionality, however, should not be expected. 


\section{REFERENCES}

Acar, M. (2007). Milton Friedman ile Özgürlük, Piyasa, Hayek, Keynes ve Pinochet Üzerine, Liberal Düşünce Dergisi, (48), 181-197.

Alpago, H. (2018). İktisadi Düşünce Tarihi (Güncel ve Eleştirisel Bir Bakış Açısıyla), Çizgi Kitabevi, Konia.

Atbaş1, F. D. (2016). Kriz, Kapitalizm ve Keynes, Toplum ve Demokrasi Dergisi, 3(6), 67.

Akalın, U. S. (2016). Sunuş: Keynes ve Genel Teori Üzerine Kısa Bir Not, Toplum ve Demokrasi Dergisi, 3(6).

Benati, L. (2009). Long Run Evidence on Money Growth and Inflation, Social Science Research Network, Rochester, NY 10.

Bordo, M.D. (2010). Monetary policy, history of, in Monetary Economics, London: Palgrave Macmillan UK.

Bryan, M. (1997). On the Origin and Evolution of the Word Inflation, in Economic Commentary, October 15.

Birinci, Y. (2011). Enflasyon, Para Politikası ve Stratejileri, İstanbul Üniversitesi İktisat Fakültesi Mecmuası, 47, 1-4.

Erdoğan, S. (2005). Alternatif Para Politikası Stratejileri Üzerine Karşılaştırmalı Bir Değerlendirme, Kocaeli Üniversitesi Sosyal Bilimler Dergisi, (9), 34-54

Friedman, M. (1995). The Role of Monetary Policy, in Essential Readings in Economics, Macmillan Education UK, London.

Görgün, S. (2012). Enflasyon ve Stagflasyon, İstanbul Üniversitesi Siyasal Bilgiler Fakültesi Dergisi, 0(10).

Illing, G. (2009). Makroökonomie, 5. Edition, Pearson Studium, München.

Hiç Birol, Ö. (2013). Klasikler, Marx, Keynes ve Sonrasi:Laissez-Faire Liberalizminden Günümüz Piyasa Ekonomisine, Trakya Üniversitesi Sosyal Bilimler Dergisi, 15 (2), 95 110 .

Krugman, P. (2021). Stagflation revisited. Did we get the whole macro story wrong?. https://paulkrugman.substack.com/Semptember 2021

O’Neill, R. (2017). What Is Inflation? In: Inflation. Springer International Publishing, Cham Risse, S. 82021), Die Inflation kommt, E-Books, FinanzBuch Verlag, München.

Steele, G. R. (1989). Introduction, in Monetarism and the Demise of Keynesian Economics, London: Palgrave Macmillan UK.

Sever, E., Demir, M. (2015). Enflasyon Hedeflemesi Sürecinde Enflasyon ve Enflasyon Belirsizliği Ilişkisinin Analizi, Marmara Üniversitesi İktisadi ve İdari Bilimler Dergisi, 24 (1), 41-63

Tobin, J. (1972). Inflation and Unemployment, The American Economic Review, 62 (1/2), 118. 